\title{
STUDIES ON CARBONIFEROUS INSECTS OF COMMENTRY, FRANCE: PART VI. THE GENUS DICTYOPTILUS (PALAEODICTYOPTERA)*
}

\author{
By F. M. Carpenter \\ Harvard University
}

The genus Dictyoptilus was established by Brongniart in 1893 for a single species, renaulti, based on two small wing fragments. It was placed by Brongniart in the series of Palaeozoic insects which he termed the "Sténodictyoptérides" and which he assigned to the "Primitive Neuroptera". Two very closely related species were subsequently described by Meunier (1908, 1910) in a new genus, Cockerelliella. Although the Meunier specimens are very well preserved, the published accounts of them by Meunier, Handlirsch, and Lameere have not included their venational details, which turn out to be very important for the determination of the phylogenetic position of Dictyoptilus. From a study of these fossils, made at the Laboratoire de Paléontolgie in Paris, in 1938 and 1961, I am convinced that Dictyoptilus is very close to the Permian genus Eugereon and should be included in the family Eugereonidae of the Order Palaeodictyoptera; that the venation of the hind wing of the Eugereonidae has been basically misinterpreted, the pattern being very different from that of the fore wing; and that the wings of Eugereon were actually long and slender, not short and broad, as formerly assumed. The reasons for these conclusions will be given after the descriptions of the Commentry fossils belonging to Dictyoptilus.

\section{Family Eugereonidae Handlirsch, I906}

Eugereonidae Handlirsch, 1906, Foss. lns., p. 388

Dictyoptilidae Lameere, 1917, Mus. Nat. Hist. Natur., Bull. 23 :194

Fore wing: slender, costal margin very nearly straight, not arched; Sc long; Rs arising near wing base, with 4 or 5 main branches; stem of $M$ arising independently at base, then aligned with $R$ for a short distance before diverging away; $M$ forking near the level of origin of Rs; MA unbranched; MP branched; $\mathrm{Cu}$ curving towards $\mathrm{M}+\mathrm{R}$ at very base, then parallel to it before dividing; $\mathrm{CuA}$ diverging towards $\mathrm{M}$ shortly after its origin, unbranched; $\mathrm{CuP}$ forked; several

*This research has been aided by National Science Foundation Grant No. GB 2038. The previous paper in this series was published in Psyche, 70: 240-256, 1963. 
anal veins arising from one stem. Cross veins numerous, forming a reticulation in some areas of wing.

Hind wing: shape apparently as in fore wing; Rs diverging away from $\mathrm{Rl}$ after its origin; base of $\mathrm{M}$ apparently independent of $\mathrm{R}$, curved; MA arising at about level of origin of Rs, ending at the position of termination of $\mathrm{CuA}$ in fore wing; $\mathrm{CuP}$ forking into at least 4 terminal branches; $\mathrm{CuA}$ strongly curved.

Body structure (known only in Eugereon): head small, with slender haustellate beak [For details of body structures see Dohrn, I867; Handlirsch, I906].

This family is represented in the Commentry shales by the single genus Dictyoptilus.

\section{Genus Dictyoptilus Brongniart}

Dictyoptilus Brongniart, 1893, Recherches Hist. Ins. Foss.:390; Handlirsch, 1906, Foss. Ins.:66; Lameere, 1917, Mus. Nat. Hist. Natur., Bull., $23: 103$ Cockerellia Meunier, 1908, (non Cockerellia Ashmead, 1898), Ann. Soc. Sci. Brux., $32: 154$

Cockerelliella Meunier, 1909, Ann. Paléont., 4:132

Fore wing: long and slender, the length more than five times the width; posterior margin with two slight indentations, one near $\mathrm{R}_{5}$ and the other near the end of the posterior branch of $\mathrm{MP}_{2}$. Sc extending almost to wing apex, $\mathrm{R}_{\mathrm{I}}$ terminating at very apex; $\mathrm{Rs}$ and MA arising at about the same level; Rs with five or more branches; MP dividing into $M P_{1}$ and $\mathrm{MP}_{2}$ directly after its origin; $\mathrm{CuA}$ diverging towards $M$, as characteristic of the family, and either touching or not quite touching $\mathrm{M}$; cross veins numerous; those in the costal and subcostal areas straight and unbranched; those in other areas straight or reticulate, forming a coarse, irregular network in many parts of the wing.

Hind wing: known only in D. peromapteroides (Meunier) ; shape apparently as in fore wing, with a slightly broader base; space between Rs and MA much broader than that between MA and MP.

Body unknown.

Type-species: Dictyoptilus renaulti Brongniart, I893 (by monotypy).

The generic characteristics suggested above are tentative, since only one other genus, Eugereon, is known in the family, and since only the basal parts of the wings are known in that genus. ${ }^{1}$ Dictyoptilus

\footnotetext{
${ }^{1}$ The Commentry genus Archaemegapt.lus Meunier (1908), which Lameere (1917) considered close to Dictyoptilus, seems to me to require family separation; the wing is relatively broad and lacks the basal divergence of $\mathrm{CuA}$. The family Archaemegaptilidae, established by Handlirsch (1919, p. 13) for this genus, appears to be valid.
} 


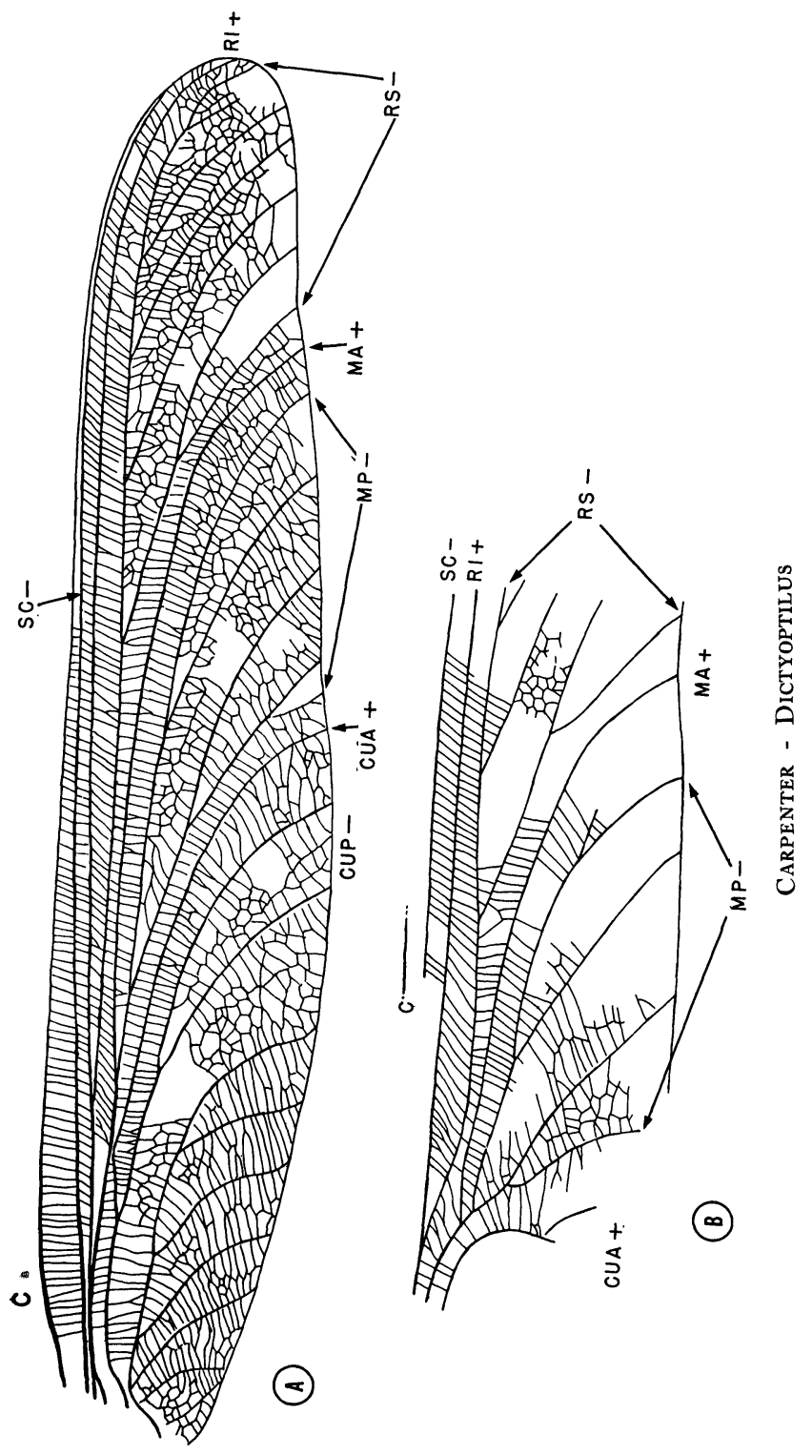


seems very similar to Eugereon on the basis of the parts of the wings known in both genera. The basal portions of the fore wings are, in fact, so much alike that generic distinction is not apparent; the hind wings, however, show a few differences, e.g. the area between $\mathrm{Rs}$ and MA in Eugereon is fully twice as wide as that of Dictyoptilus.

The type-species of Dictyoptilus (renaulti) is known only from two specimens, each consisting of the middle part of a fore wing. However, the venational pattern included is so much like that of the type-species of Cockerelliella (peromapteroides) that the generic synonomy given above seems obvious.

Dictyoptilus is at present known only from the Commentry shales, in France. Two species (sepultus and peromapteroides) have been described in addition to renaulti. These are quite clearly very close and might well belong to one species. However, since the specific names, which have already become established in the literature, provide convenient means of referring to individual specimens, I am treating them as distinct.

\title{
Dictyoptilus renaulti Brongniart
}

Dictyoptilus renaulti Brongniart, 1893, Recherches. Hist. Ins. Foss.: 391, pl. 22, figs. 13,14; Lameere, 1917, Mus. Nat. Hist. Natur., Bull. $23: 103$.

This species was based on the two specimens (herein designated 22-I3 and 22-14) figured in Brongniart's Recherches, each representing middle portions of a wing. Specimen 22-14 was examined by me at the Museum National, but 22-13 could not be found in the collection. The former is presumably part of a fore wing, on the basis of its venation ; $^{2}$ the venation of the hind wing beyond the basal part is unknown in Dictyoptilus.

Brongniart's figure of this fossil is correct, as noted by Lameere

\begin{abstract}
${ }^{2}$ Brongniart's figure shows a minute fragment of another wing in front of the wing of renaulti, which suggests that the latter was a hind wing. However the venation of specimen $22-14$ is not like that of a hind wing, as known in peromapteroides; and the figures in Brongniart's Recherches, although generally accurate so far as the fossils are concerned, are often imaginary with respect to the presence of other fossils on the individual pieces of shale. See Carpenter 1943, p. 529-530.
\end{abstract}

Explanaton of Plate 13

Fig. A. Dictyoptilus sepultus (Meunier), original drawing of fore wing based on type in Laboratoire de Paléontologie, Paris. Fig. B. Dictyoptilus peromapteroides (Meunier) original drawing of hind wing based on type in Laboratoire de Paléontologie, Paris.

Lettering: c. costa; Sc. subcosta ; RI. radius; RS, radial sector ; MA, anterior media; $\mathrm{MP}$, posterior media; $\mathrm{CuA}$, anterior cubitus; $\mathrm{CuP}$, posterior cubitus; - concave veins; + , convex veins. 
(1917). The length of the specimen is $32 \mathrm{~mm}$. and its width $19 \mathrm{~mm}$. Comparing this fragment with the corresponding part of the complete wing of D. sepultus (Meunier), I estimate that the fragment is about $\mathrm{I} / 5$ the total wing length, indicating that a complete wing of reuaulti would be about $160 \mathrm{~mm}$. long.

\section{Dictyoptilus sepultus (Meunier) \\ Plate I3, Fig. A; Plate I4}

Cockerellia sepulta Meunier, 1910, Ann. Soc. Sci. Brux., 34:195; Meunier, 1910, Mus. Hist. Nat., Bull. $16: 235$, fig. 3.

Cockerelliella sepulta, Meunier, 1912, Ann. Paleont., 7:6; pl. 6, fig. 4, 4a.

Dictyoptilus sepultus, Lameere, 1917, Mus. Nat. Hist. Natur., Bull., $23: 160$.

This species is based on a single, excellent fossil, consisting of a complete fore wing; the veins and cross veins are very clearly preserved. In one counterpart (the obverse, with Sc concave) the distal third is missing but the rest is exceptionally clear; in the reverse, the basal quarter is missing but the distal portion is very well preserved. Figure A, plate I3, is a drawing of a complete wing, based on the two counterparts. The total wing length is $106 \mathrm{~mm}$., which is about $50 \mathrm{~mm}$. less than the wing length of renaulti. The wing of sepultus has a maximum width of about $20 \mathrm{~mm}$. The venation presents no problems in homology, the convexities and concavities being strongly indicated. There are two noteworthy aspects of the venation, however. ( I ) $M$ arises as an independent vein at the wing base, but shortly diverges anteriorly and continues in contact (but not anastomosed) with $\mathrm{R}$ for a short distance, forming a double vein; it then separates off as an independent vein. (2) $\mathrm{Cu}$ at its base is directed anteriorly but shortly runs parallel with $\mathrm{R}+\mathrm{M}$, and then divides into $\mathrm{CuA}(+)$ and $\mathrm{CuP}(-)$. $\mathrm{CuA}$ diverges anteriorly at this point, touching, but not anastomosing, with $\mathrm{M}$ before diverging away again. These unusual features are duplicated in Eugereon, as noted below.

Lameere (I9I7, p. I60) has stated that there is a small precostal space at the base of the wing. A slight thickening of the wing is visible at the base, but I am not convinced that it is actually a precostal area. Lameere also states that the subcosta terminates well befofe the wing apex, as it is shown in Meunier's figure (I9IO) and also in Handlirsch's (1919). Laurentiaux (1957) in an original figure shows Sc extending a little further than indicated in the previous figures. I am convinced from my study of the fossil (as well as of the type of peromapteroides) that Sc extends even further towards the apex; at any rate, it is still identifiable as a distinct vein up to that point (See plate 14 ). 
Meunier's figure of this fossil (I910, p. 236) is unbelievably inaccurate. Handlirsch's illustration (I9I9, p. I2), although not so crudely done as Meunier's, is erroneous in several major respects, i.e., short Sc, and the absence of the divergence on $\mathrm{CuA}$. Laurentiaux's figure (1953, p. 423) is accurate in all important aspects, but shows a fork on the penultimate branch of Rs, instead of the terminal one.

As noted above, this species is very close to renaulti, but the difference in size is sufficient to retain the species as distinct.

\section{Dictyoptilus peromapteroides Meunier Plate 13, Fig. B}

Cockerellia peromapteroides Meunier, 1908, Ann. Soc. Sci. Brux., 32:154; Meunier, 1907, Mus. Hist. Natur., Bull., 14:36, fig. 2.

Cockerelliella peromapteroides, Meunier, 1909, Ann. Paléont., 4:132, pl. 1, fig. 3.

Dictyoptilus peromapteroides, Lameere, 1917, Mus. Nat. Hist. Natur., Bull., $23: 159$.

This species is based on a single specimen consisting of a nearly complete fore wing and the basal half of a hind wing; the preservation is satisfactory, although not so good as that of the type of sepultus. The fore wing as preserved is $130 \mathrm{~mm}$. long and has a maximum width of $22 \mathrm{~mm}$.; the complete length of the wing was probably about I $40 \mathrm{~mm}$. The venation of the fore wing seems to be very close to that of sepultus; in fact, it is difficult to find differences. The cross veins appear to be a little closer together than those of sepultus and the reticulation formed by the cross veins a little finer. The fore wing is about $25 \mathrm{~mm}$. longer than that of sepultus and $30 \mathrm{~mm}$. shorter than that of renaulti.

The type specimen of peromapteroides is especially interesting because of the presence of the hind wing, which is otherwise unknown in Dictyoptilus. Meunier's figure of the hind wing ( 1908, p. 36) is very misleading. Handlirsch's figure (I9I9, fig. I3), which was made by a tracing from Meunier's published photograph of the fossil, is better than Meunier's but misses many of the important features noted below. Lameere (I9I7) in his brief notes on peromapteroides makes no comment on the peculiarities of the venation of the hind wing.

The hind wing is preserved only to about the level of the middle of the fore wing; at this point it is clearly broken away. There is no indication that the hind wings were substantially shorter than the fore wing, as shown in Handlirsch's figure (1919); the distal part of the fragment of the hind wing measures $20 \mathrm{~mm}$. in width, which is only $2 \mathrm{~mm}$. less than the fore wing at that position. So far as is 


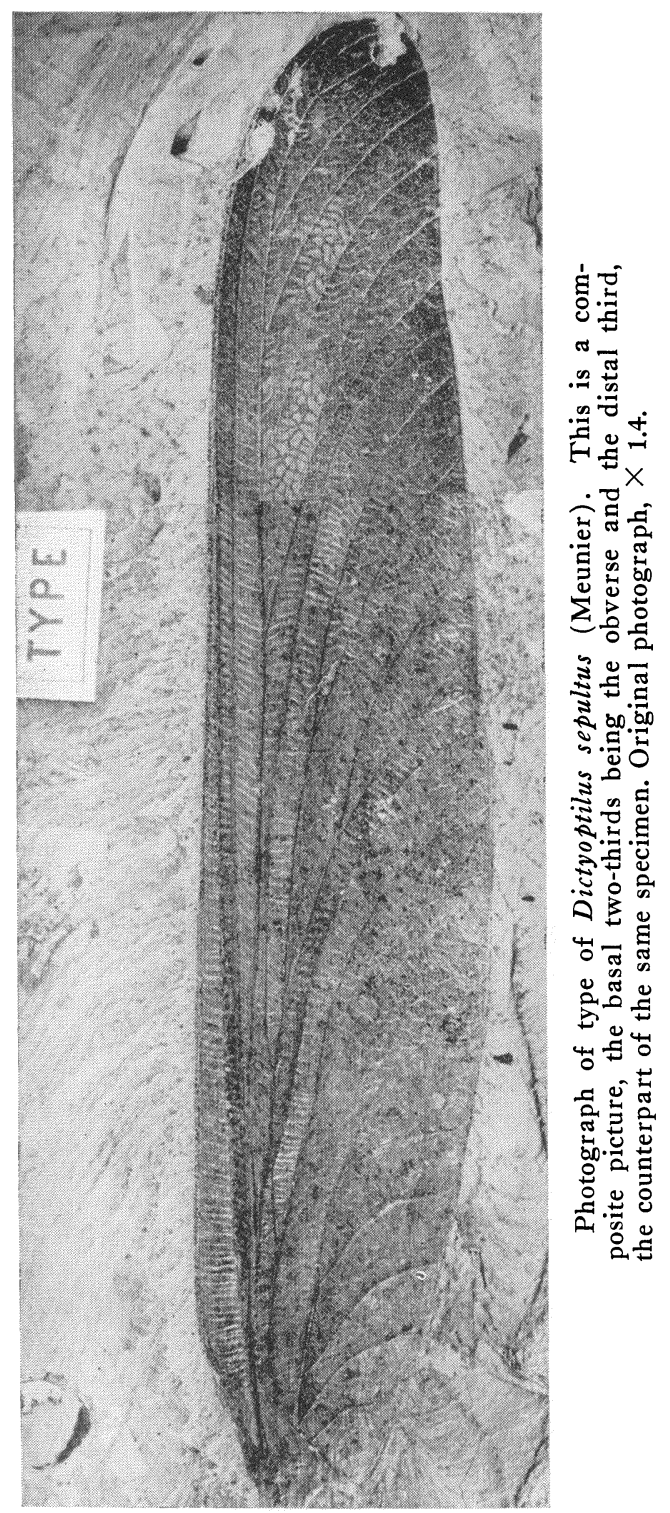


known at the present time, therefore, the hind wing was of the same length or nearly the same length as the fore wing. The accompanying drawing (Plate 13 , fig. B) of the hind wing of peromapteroides was made from the type specimen in the Museum National in Paris in I 938 and was verified by checking with the specimen in 196r. The costal margin of the hind wing is not actually visible in the fossil; the basal part is covered up by the hind margin of the fore wing and beyond that point it is broken away; there is, at most, a faint indication of what might be a short piece of the margin just beyond the edge of the fore wing. The first vein which is clearly apparent in the wing is, therefore, the subcosta, which is preserved as a concave vein. Below that, the vein $\mathrm{Rl}$ is readily recognizable as a strong convex vein; its basal part is not preserved, being covered by the fore wing. Rs is very closely preserved as a concave vein but unlike $R s$ in the fore wing, it diverges posteriorly away from $\mathrm{Rl}$ and then turns towards $\mathrm{Rl}$; the space between Rl and Rs is actually wider shortly after the origin of Rs than it is further along in the wing. In the part of the wing preserved, Rs gives rise, in a pectinate manner, to three concave branches, separated by several rows of cellules. Rs in the hind wing, therefore, differs from that in the fore wing by its more basal origin and earlier branching. The rest of the venation of the hind wing is even more different from that of the fore wing. The next vein, which is not obviously convex or concave, arises near the base and is slightly curved; it first gives rise to a strong convex vein, and beyond that it forks to produce two major branches, each in turn forking; this whole system is composed of concave veins. The convex veir. I am identifying as MA, since it follows the distinctly concave Rs; the concave veins below that would appear to be MP. The next and only remaining vein preserved in the wing is a strongly curved, convex vein, apparently $\mathrm{CuA}$; this is not preserved to its termination but the part that is present is almost semicircular. It is difficult to imagine what the distal portion of this hind wing was like; Rs was apparently extensively developed distally, no other main veins remaining. As noted above, there is no evidence that the hind wing was markedly shorter than the fore; the slight indentation of the hind margin corresponds to the first indentation of the fore wing margin. At any rate, it is obvious that the fore and hind wings in Dictyoptilus are remarkably different in venation - more so, in fact, than those of any other Palaedictyoptera known. The fore and hind wings of even those genera (as Dunbaria) which show differentiation of wing form, have a similar venation, except for the number and length of anal veins. 
The Affinities of Dictyoptilus

As mentioned above, Brongniart, who did not accept Goldenberg's order Palaeodictyoptera, placed Dictyoptilus with several other genera, without formal family assignment, in his "Néuroptères Primaires". Handlirsch (I906) included the genus in the family Dictyoneuridae of the order Palaeodictyoptera. Of course, both Brongniart and Handlirsch knew the genus only by the small fragments representing the type-species, renaulti. In I9I7 Lameere, who used a unique system of classification that virtually excluded extinct orders, ${ }^{3}$ erected the family Dictyoptilidae for the genus and five other genera (Archaemegaptilus, Peromaptera, Protagrion, Gilsonia, and Meganeura), indicating that he was including the "Protodonates" in the Dictyoptilidae. That familv along with two others (Dictyoneuridae, Fouqueidae) he included in a major division of the winged insects, the Odonatoptères. From this classification, it is apparent that Lameere regarded Dictyoptilus as more closely related to the obvious odonate types, such as Meganeura, than to the palaeodictyopterous types, such as Dictyoneura and Stenodictya. In his discussion of the group which he terms the Protodonates ( I9I 7, p. I86) Lameere gives as part of the evidence for this position of Dictyoptilus the presence of a precostal space at the base of the fore wing and he also points to similarities in venation between Dictyoptilus and such forms as Protagrion, which is, however, now placed in the Palaeodictyoptera (Carpenter, I943). As noted above, I am not convinced that there is a true precostal space present in any of the specimens of Dictyoptilus.

Handlirsch in I9I9, not accepting Lameere's synonomy of the genus Cockerelliella with Dictyoptilus, erected the family Cockerelliellidae, which he placed in the Palaeodictyoptera. He assigned Dictyoptilus to the family Dictyoneuridae, as previously. In his posthumously published paper of 1937, Handlirsch reviewed Lameere's classification, stating his conviction that the Dictyoptilidae of Lameere were a mixture of odonate and of true palaedictyopterous types. In this work he recognized the family Dictyoptilidae in the sense of his previous family Cockerelliellidae, placing it in the Palaeodictyoptera. In I 935 Lameere still put Dictyoptilus in the Odonoptères but within the Sténodictoides, thus separating it from the Odonata and Protodonata (Odonatoides).

From the above summary it is apparent that Handlirsch and finally Lameere were convinced that Dictyoptilus was most closely related

\footnotetext{
${ }^{3}$ The order Pseudohemiptera (=Protohemiptera) was the only extinct order recognized by Lameere.
} 
to the primitive families (e.g., Dictyoneuridae) of the order Palaeodictyoptera. A different view has been advanced by Laurentiaux (1957), who associates it with the family Eugereonidae, which has included a single genus from the Permian of Germany, and which has become well known because of the presence of a haustellate beak. Eugereon was designated by Handlirsch ( 1906) the type-genus of a new order (Protohemiptera) but it has been included by most students of Palaeozoic insects in the Palaeodictyoptera. Lameere (I935), however, separated the group, which he termed the Pseudohemiptera, from the palaeodictyopterous families (including Dictyoptilidae) by superordinal lines. Laurentiaux (1953) has elevated the Palaeodictyoptera to a superorder and has recognized the Protohemiptera as an order within that complex. In addition to the Eugereonidae and Dictyoptilidae, Laurentiaux has included within the Protohemiptera the Protagrionidae (based on the monotypic genus Protagrion) and the Calvertiellidae (based on the monotypic genus Calvertiella). For reasons which will be apparent in the following discussion, I believe Laurentiaux is right in associating Dictyoptilus with Eugereon but I do not believe there is evidence to justify the inclusion of Protagrion and Calvertiella in the same complex.
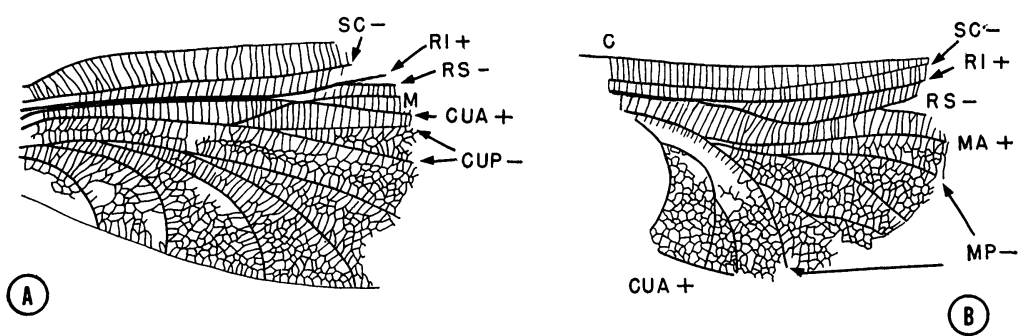

Text-fig. 1. Eugereon boeckingi Dohrn. A. fore wing; B, hind wing. Original drawings based on photograph of type sent by Dr. Paul Guthörl, Lettering as in Plate 13.

A detailed study of the venation of Dictyoptilus indicates that this genus is actually closer to Eugereon than has been assumed even by Laurentiaux and, as I have mentioned above, I consider that the two belong to the same family. The basal part of the fore wing, for example, is strikingly similar to that of Eugereon (text-fig. I); the stem of $M$ arises precisely the same and forms a double vein with the stem of R, although in Eugereon the double vein is somewhat longer than it is in Dictyoptilus. The stem of $\mathrm{Cu}$ arises in the same fashion in both of these genera and $\mathrm{CuA}$ diverges anteriorly and touches the 
stem of M. The structure of MA and of MP is essentially the same in the two genera. The anal veins of Dictyoptilus are similar to those of Eugereon except that they are not quite so strongly curved near the base of the wing. However, it is when we compare the hind wings of these two genera that we find the similarities most striking. Rs, after its origin from Rl, diverges away the same way in the two genera and then gives rise to the first of the pectinate branches. The media is curved in both genera and produces the strongly convex MA and after a very short interval MP divides to form the two main concave branches. $\mathrm{CuA}$ appears in essentially the same form in both genera.

The close relationship between Dictyoptilus and Eugereon now seems obvious; the similarities of the fore wings might be due to convergence but the similarities of the remarkably specialized hind wings, even in minor venational details, make this explanation untenable. The affinities of these two genera have two interesting implications regarding Eugereon. Since the hind wing of Dictyoptilus is better and more extensively known than that of Eugereon, our previous interpretations (Handlirsch, 1906) of the venation of Eugereon now seem to require modification: the vein which has been interpreted as the media in the hind wing is actually the radial sector (Rs) and the former cubitus now turns out to be MA and MP. It might be noted in this connection that Handlirsch's figure of the hind wing of Eugereon ( 1906) shows the very beginning of a branch originating from the vein herein indicated as Rl. Since Rl very rarely carries branches in any insect (except distally), Handlirsch apparently identified this vein as the base of the radial sector, which would, of course, be consistent with his interpretation of the next vein as the media. However, no fork or branch of this vein (R1) is shown by Dohrn in his original figure of Eugereon or by any of the other workers who have studied the fossil, and none shows in a photograph of the specimen sent to me by the late Dr. Paul Guthörl. ${ }^{4}$ Furthermore, it is now obvious from the convexities and concavities preserved in the hind wing of Dictyoptilus that the subsequent vein (herein designated as Rs) is a concave vein and that all of its branches are concave; if this vein were the media, it should (in the Palaeodictyoptera) be convex or at any rate have a convex anterior branch (MA).

The second implication with respect to Eugereon is the shape of the wings. Although only the basal portions of the wings are preserved

\footnotetext{
${ }^{4}$ The figure of Eugereon included in the Osnovy (B. P. Rohdendorf, 1961, figure $40 \mathrm{~B}$ ) shows the branch on $\mathrm{Rl}$, but that illustration was copied from Handlirsch, 1906.
} 
in the fossil, Handlirsch has presented a detailed restoration of the entire insect (I92I), which shows the complete wing as curiously shaped, short and broad. Haupt (1949), basing his conclusions on the same unique specimen, has given another restoration, which shows equally strange but short wings ${ }^{5}$. Actually, of course, there is no evidence whatever for the peculiar shapes of the wings depicted by Handlirsch and Haupt. Indeed, from the similarity of Dictyoptilus to Eugereon, it now becomes virtually certain that the fore wing of Eugereon was long and slender as in Dictyoptilus and that the hind wing was similarly shaped.

Although the Eugereonidae, as conceived here, includes species in which the venational patterns of the fore and hind wings are markedly different, I see no reason for separating the group into a distinct order, as has been done by Laurentiaux. Very little is actually known about most genera of Palaeodictyoptera and as indicated by the history of Dictyoptilus and Eugereon, discussed above, when more information is obtained, it is usually quite different from what was expected. Attempts to divide the Palaeodictyoptera into suborders and superfamilies, as has been done by Rohdendorf (196I) or into orders, as has been done by Laurentiaux (1953) seems to me to be useless nomenclature in the present state of our knowledge of Palaeozoic insects. The evidence at hand suggest that the order Palaeodictyoptera was a very large and diverse group - far more diverse than we have realized - but still monophyletic. It seems highly probable on the basis of the history of other groups of animals that these early winged insects underwent a rapid, radial evolution, but until more structural details are known (e.g., both fore and hind wings, body structure, etc.), I believe we cannot untangle the numerous lines of evolution.

\section{REFERENCES}

Brongniart, C.

1893. Recherches pour servir à l'histoire des insectes fossiles des temps primaires. Soc. Industr. Minerale, Bull., 7:124-615, pls. 17-53; also published as Thèse Fac. Sci. Paris, 821, pp. 1-494, pls. 1-37. (All page and plate citations in the present paper refer to the Thése, since this is the only form of Brongniart's work usually DoHrn, A. available.)

1866 Eugereon boeckingi. Palaeontographica, 13 :333-340, pl. 41.

1867. Zur Kenntnis der Insekten in der Primärformation von Saarbrücken. Palaeont. 14:129-134, pl. 8.

${ }^{5}$ Both of these restorations are included in Haupt's paper (1949, page 33). The best published photograph of the actual specimen of Eugereon is included in Handlirsch, 1906, plate 38. 
Handirirch, A.

1906. Die Fossilen Insekten, Wien.

1919. Revision der Paläozoischen Insekten, Denkschr. Akad. Wissenschaften Wien, Math.-Naturwiss. Klass, 96:1-82.

1921. Palaeonotologie, in Schröder, Handbuch der Entomologie, $3: 117-306$.

HAUPT, $\mathrm{H}$.

1949. Reconstruktionen permokarbonischer Insekten. Beitr. tax. Zool., $1: 23-43$

LAMEERE, A.

1917. Revision sommaire des insectes fossiles du Stephanien de Commentry. Mus. Nat. Hist. Natur., Bull., $23: 141-201$

1935. Précis de Zoologie, 4:255-256.

Laurentiaux, D.

1953. Classe des insectes, in Piveteau, Traité de paléontologie, $3: 396-527$.

Meunier, F.

1908. Nouveaux Paléodictyoptères du Stéphanien de Commentry.

Mus. Hist. Natur., Bull. 14:34-36.

1909. Nouvelles recherches sur les insectes du terrain houiller de Commentry. Ann. Paléont., 4:125-152.

1910. Nouveaux Paléodictyoptères du houiller de Commentry. Mus. Hist. Nat., Bull., 16:233-237.

1910. Une nouvelle espèce de Paléodictyoptère (sténodictyoptère Brongniart) du terrain houiller de Commentry. Ann. Soc. Sci. Brux., $34: 195-196$.

1912. Nouvelles recherches sur quelques insectes du terrain houiller de Commentry. Deuxième partie, Ann. Paléont., 7:1-19.

ROHDENDORF, B. B.

1962. Osnovy, 9:50-51. 

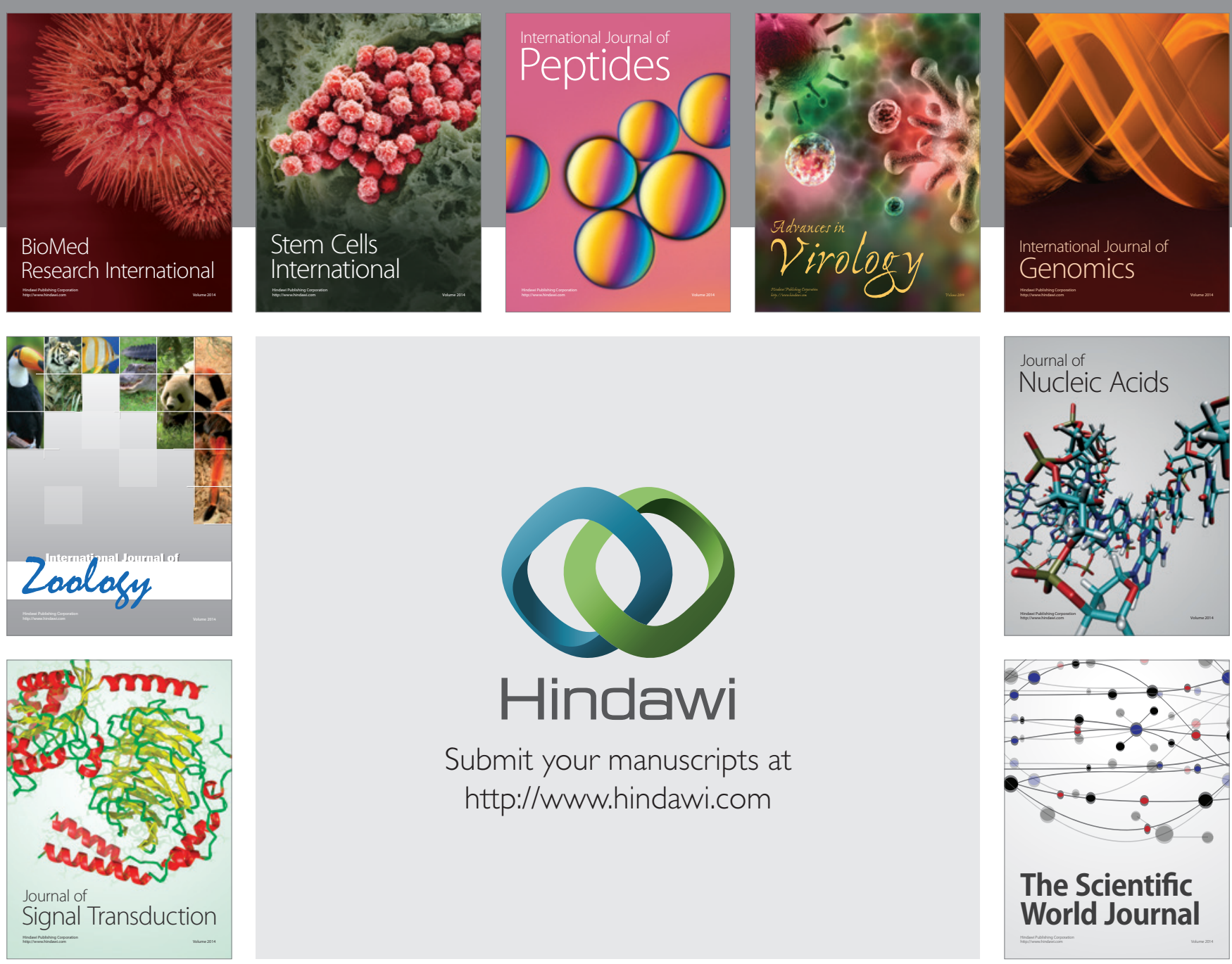

Submit your manuscripts at

http://www.hindawi.com
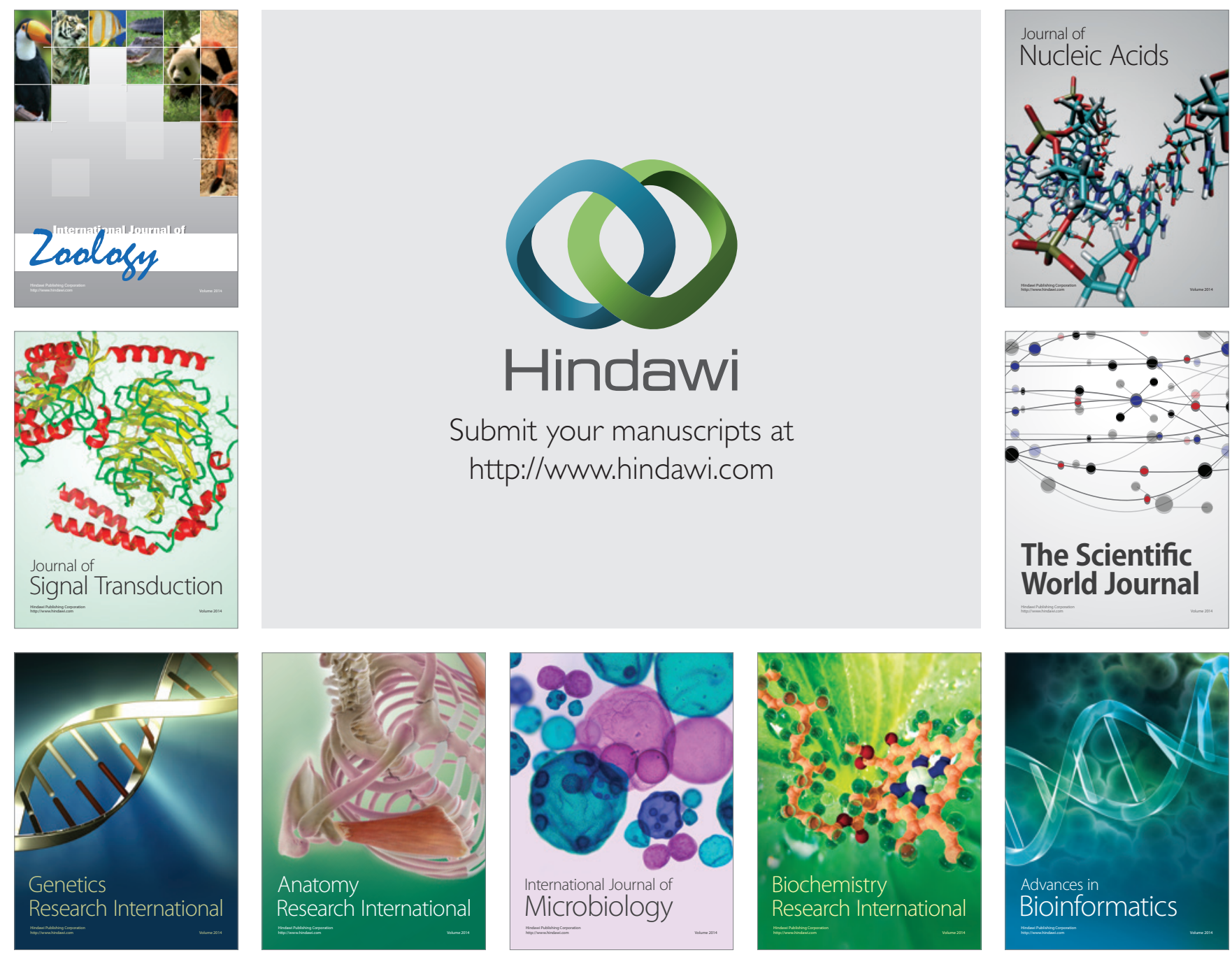

The Scientific World Journal
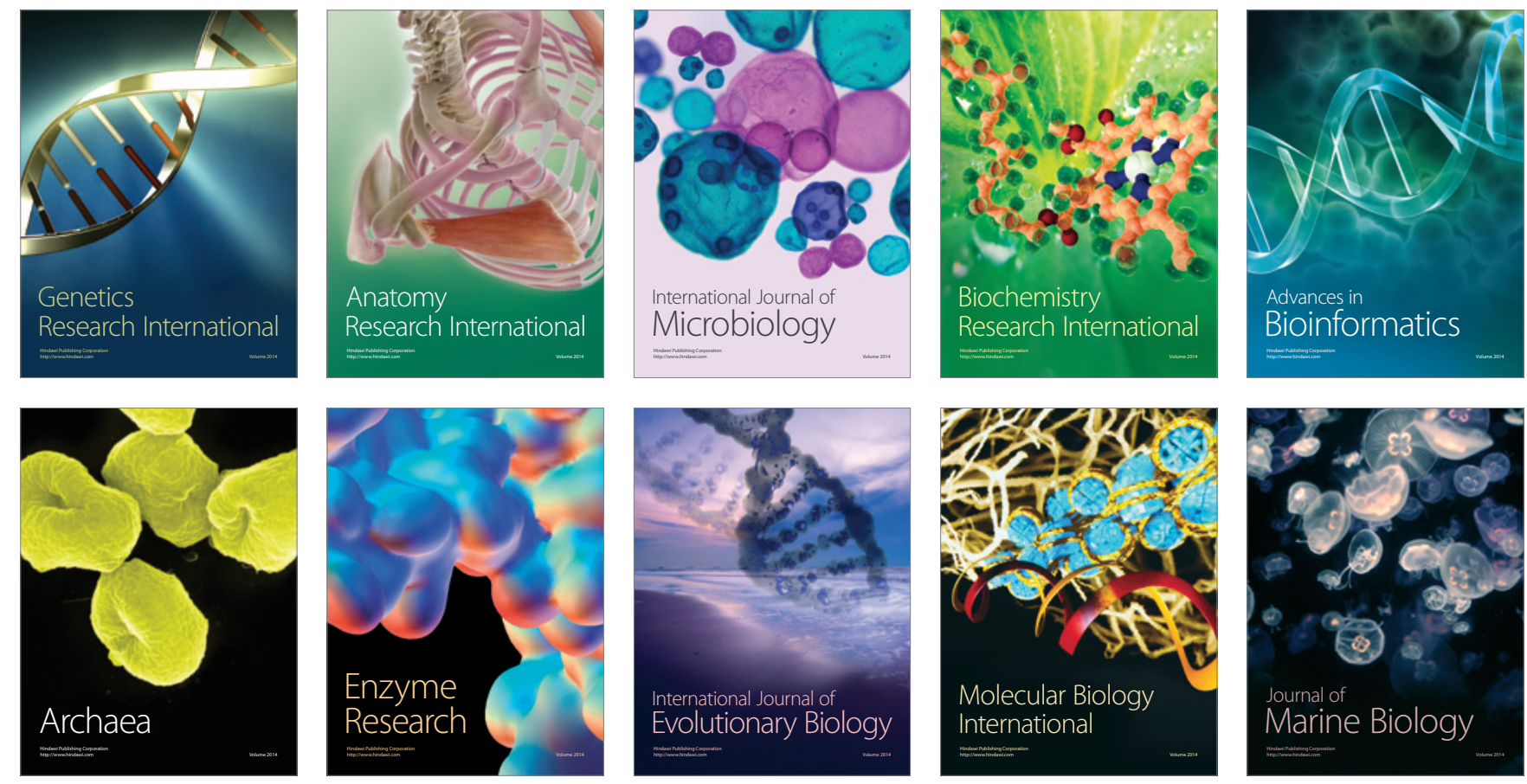